Ewa Wysocka

https://doi.org/10.26881/pwe.2018.42.13

ORCID: 0000-0003-0298-3234

Uniwersytet Śląski

ewa-wysocka@hot.pl

Jolanta Pulka

ORCID: 0000-0002-8691-0480

Krakowska Akademia im. Andrzeja Frycza Modrzewskiego

jolanta.pulka@gmail.com

\title{
Postawy twórcze dzieci w młodszym wieku szkolnym - tendencje zmian
}

\section{Summary \\ Creative attitudes among young school children - trends of change}

In the article, the authors put forward and develop a thesis on the regression of creative attitudes in the course of school education. The process of developing creative attitudes among children is analyzed in the perspective of the role and objectives of school education. The authors examine the level and dynamics of the development of creative attitudes in the course of school education (the first 3 years of early school teaching). Creative attitudes include: divergent thinking, creative motivation, and strategies of coping with difficult tasks (intrapersonal and interpersonal strategies). The research was conducted on a representative nationwide sample. The data gathered as a result of this research point to a low level of creative attitudes among early school children, and their negative development in the course of school education.

Keywords: creative attitudes, divergent thinking, creative motivation, development of creative attitudes, intrapersonal and interpersonal strategies of coping, education towards creativity

Słowa kluczowe: postawy twórcze, myślenie dywergencyjne, motywacja twórcza, interpersonalne i interpersonalne strategie radzenia sobie, rozwój postaw twórczych, edukacja do twórczości

\section{Wprowadzenie}

Dobre wprowadzenie w tematykę artykułu stanowią słowa Kena Robinsona, który twierdzi, że „... wielu niezwykle utalentowanych, genialnych ludzi nie uważa siebie za takich, ponieważ to, w czym byli dobrzy, nie było w szkole doceniane albo było wręcz napiętnowane. Konsekwencje takiego stanu rzeczy są katastrofalne zarówno dla jednostek, jak i dla zdrowia wspólnot, w których żyjemy" (Robinson, Aronica 2015: 14). Proces ten 
zaczyna się w momencie podjęcia nauki szkolnej, stąd wymaga szczególnej uwagi. Tym bardziej, że wyniki badań w obszarze psychopedagogiki twórczości dowodzą, że stymulowanie aktywności twórczej to ważny czynnik rozwoju, gdyż rozwija wrażliwość zmysłową, wyobraźnię, pomysłowość, płynność, giętkość i oryginalność myślenia, umiejętność odkrywania i formułowania problemów, otwartość myślenia i samodzielność sądów, wewnętrzną motywację zadaniową czy umiejętności rozwiązywania problemów (Dyrda 2004: 11). Kształtowanie postaw twórczych wymaga jednak stworzenia odpowiednich warunków ich rozwoju. Anna Brzezińska (1988: 6) wskazuje istotne czynniki rozwijania aktywności twórczej dzieci młodszych: warunki materialne, umożliwiające twórczą działalność z wykorzystaniem różnych środków i materiałów; warunki emocjonalno-wspierające, związane z tworzeniem atmosfery zapewniającej poczucie bezpieczeństwa; warunki metodyczne, określające sposób organizowania kreatywnej działalności przez stymulowanie i inspirowanie lub niedyrektywne kierowanie.

Przesłanki te czynią twórczość jednym z najważniejszych celów współczesnej edukacji, zadania planowo realizowanego przez szkołę, stąd też wpisanego w funkcję, rolę i powinności nauczyciela. Choćby dlatego, że twórczość jest tym szczególnym rodzajem aktywności człowieka, która w największym stopniu wyzwala potencjały, angażuje i ujawnia zdolności, służąc rozwojowi osobowości. Reformy edukacyjne muszą zmienić swój charakter i ukierunkowanie, tak by pielęgnować zróżnicowane talenty uczniów. Wiąże się to z zaniechaniem kontynuowania idei standaryzacji, szkodliwej zarówno dla ucznia, jak i szkoły, która musi zostać zastąpiona edukacją bardziej zrównoważoną, spersonalizowaną i kreatywną, wrażliwą na indywidualne zasoby ucznia i na nich skoncentrowaną, ale jednocześnie zorientowaną na społeczności (Robinson, Aronica 2015: 13-14)). Ken Robinson (ibidem: 18-19) twierdzi, że: „Jeśli opieramy system edukacji na standaryzacji i ujednolicaniu i tłumimy w nim indywidualność, wyobraźnię i kreatywność, nie dziwmy się, że to właśnie robi”. A dalej, wskazując nowy cel edukacji, konstatuje, że „,... edukacja ma na celu umożliwienie uczniom zrozumienia świata wokół nich oraz naturalnych talentów tkwiących w ich wnętrzu, aby mogli stać się spełnionymi jednostkami i aktywnymi, wrażliwymi obywatelami" (ibidem: 20-21; por. Karwowski 2009a, 2009b; Limont 2004, 2005).

W naszym krótkim z konieczności opracowaniu, podejmujemy wstępną dyskusję na temat znaczenia systemu edukacji dla kształtowania postaw twórczych dziecka w młodszym wieku szkolnym.

\section{Założenia teoretyczne badań własnych}

Pedagogika stawia sobie zadanie współtworzenia koncepcji „nowego człowieka”, formułując ogólne edukacyjne credo, związane z kształtowaniem człowieka twórczego, czyli sprawczego (Kozielecki 1995: 158-162), który ma szansę poradzić sobie ze złożonością świata i skomplikowaniem własnego życia, dokonującego transgresji osobistych (samodoskonalenie), ale także transgresji publicznych (doskonalenie świata własnego 
życia). Realizacja tego zadania nie jest łatwa, co wynika zarówno ze złożoności natury ludzkiej, jak i złożoności świata, a także wielowymiarowości czynników determinujących stawanie się jednostką kreatywną, twórczą, zdolną do transgresji. Działania transgresyjne/twórcze wyznaczane są przez postawy twórcze, zaś wiążą się z celowym i świadomym przekraczaniem dotychczasowych granic kultury materialnej, symbolicznej i społecznej. Służą zaspokajaniu potrzeb wyższego rzędu, głównie samorealizacyjnych, ale też służą doskonaleniu świata, a wraz z nim i poprzez własne działania, także człowieka. Rozwój człowieka dokonuje się bowiem dzięki dwóm rodzajom aktywności: adaptacyjnej i transgresyjnej. Tendencje adaptacyjne egzemplifikują i są bliższe postawom odtwórczym, zaś tendencje transgresyjne odzwierciedlają i są bliższe aktywności twórczej, jednak obie konieczne są w rozwoju jednostki. Chcąc przetrwać i rozwijać się człowiek musi zarówno „brać od świata i być z nim w zgodzie”, jak i „dawać coś z siebie światu, nie wyrażając zgody na to, co w nim wymaga naprawy”. Obie postawy pełnią różne, ale uzupełniające się funkcje, pierwsze stanowią podstawę zachowania status quo i przetrwania świata, drugie służą jego świadomej, refleksyjnej i optymalizującej przemianie. Można też założyć, że pierwsze stanowią swoisty, choć niewystarczający, środek realizacji celu, jakim jest osiągnięcie dojrzałej orientacji transgresyjnej, wyznaczanej uogólnioną postawą twórczą.

Postawy twórcze mają niewątpliwie złożoną genezę, a ponieważ odnosimy się do badań nad dziećmi we wczesnym wieku szkolnym, to jako pedagodzy właśnie szkołę traktujemy jako przestrzeń celowego kształtowania postaw twórczych, mając przy tym świadomość, że nie jest to jedyna przestrzeń ich kreowania.

Ponieważ szczególnie interesujący dla kształtowania postaw twórczych jest młodszy wiek szkolny (7-12 lat), w którym zachodzą różne w swym charakterze, ale intensywne zmiany rozwojowe, zarówno pod względem fizycznym, jak i psychicznym, dokonałyśmy analizy podstawowych wyznaczników (wymiary postawy twórczej) i korelatów (wiek/klasa) postaw twórczych dzieci w tym właśnie okresie rozwoju. Podjęcie i kontynuowanie nauki w szkole wiąże się z koniecznością rozwiązywania zadań twórczych (trudnych), których rezultaty są oceniane, zaś ocena ta może stanowić czynnik stymulujący lub blokujący rozwój kreatywności i twórczości. Wiadomo też, że podjęcie nauki szkolnej wyznacza konieczność podporządkowania się różnym wymaganiom i wypełniania nowych obowiązków związanych z rolą ucznia. Jedną z ważniejszych właściwości psychicznych uczniów młodszych jest ciekawość otaczającego je świata, wzbudzająca dążności do działania poznawczego - zdobywania wiedzy, skorelowanej z potrzebą zrozumienia i kontroli („objęcia w posiadanie”) zewnętrznego świata. Prowadzi to do powstawania stałych zainteresowań. Potrzebom poznawczym towarzyszy potrzeba aktywności i szeroko pojętego działania, które można ukierunkować twórczo. Dlatego też egzemplifikacje empiryczne dotyczące postaw twórczych i ich rozwoju odnoszą się do wskazanej kategorii wiekowej.

Postawę twórczą ujmujemy jako „efekt czy raczej rezultat przekonań i emocji oraz zachowań" (Nęcka 2001: 20), zaś w badaniach kierowano się koncepcją postaw twór- 
czych Katarzyny Krasoń (2011: 9-21), która przyjęła tę definicję jako podstawę myślenia o twórczości dzieci we wczesnym wieku szkolnym. Autorka uznała, że postawy twórcze są egzemplifikowane przez potencjalne poznawcze (myślenie twórcze) i osobowościowe (osobowość twórcza) właściwości jednostki twórczej (Krasoń 2011: 15-18; Kubicka 1999: 55-58, 2005: 125). Wyodrębniła różne wymiary postawy twórczej, ujmując ją jako zdolności twórcze, motywację twórczą i specyficzne sposoby radzenia sobie z trudnościami (trudnym zadaniem). Wśród zdolności twórczych wyróżniła: myślenie dywergencyjne, motywację działania twórczego oraz radzenie sobie w sytuacjach trudnych w aspekcie interpersonalnym (strategia interpersonalna) $\mathrm{i}$ intrapersonalnym (strategia intrapersonalna). Zakładamy, że „proces twórczy to proces psychiczny, prowadzący do wytworzenia nowej i wartościowej idei” (Nęcka 2001: 35), zaś tworzenie wyobrażeń o sobie jako jednostce twórczej dokonuje się w momencie pobudzania dziecka określonym bodźcem (sytuacją), motywującym go do interpretacji w danej chwili. Choć niewątpliwie zależnej od doświadczeń i obrazu dziecka tworzonego przez społeczne zwierciadło (Tokarz 2005). Swoistym utrudnieniem badania postaw twórczych dzieci jest m.in. ograniczona autonomia ich przekonań (sądów na temat siebie), generowanych głównie opinią innych, znaczących dla dziecka osób. Ponadto dzieci w tym wieku nie mają ustalonych i utrwalonych przekonań na temat siebie i świata; są one pochodną przekonań ich otoczenia społecznego. Można jednak założyć, że te pierwotnie wbudowane w tożsamość dziecka, zewnętrzne przekonania, mają znaczenie rozwojowe, gdyż stanowią swoiste „,sito" selekcjonujące interpretację zarówno obecnych, jak i przyszłych jego doświadczeń (Bradshaw 1994).

\section{Założenia metodologiczne badań}

Celem badania było rozpoznanie i opis postaw twórczych prezentowanych przez dzieci w młodszym wieku szkolnym. Przedmiotem badań uczyniłyśmy twórczość dzieci przejawianą/kształtowaną w toku edukacji wczesnoszkolnej.

W publikacji zaprezentowano fragment wyników badań zespołowych z zastosowaniem metody sondażu diagnostycznego. Narzędziem badawczym, które zastosowałyśmy w badaniu była Skala Postaw Twórczych vs. Odtwórczych (SPTO), Katarzyny Krasoń (2011), przeznaczona do pomiaru postawy twórczej uczniów w wieku 7-9 lat (klasy 1-3 szkoły podstawowej). Badania przeprowadzono na próbie ogólnopolskiej w 2011 roku we wszystkich 16 województwach Polski, w 3 typach miejscowości: miastach wojewódzkich, miastach do 100 tysięcy mieszkańców oraz miasteczkach i wsiach do 10 tysięcy mieszkańców (zob. K. Krasoń 2011). Badania miały charakter poprzeczny, przeprowadzono je na próbie liczącej ogółem 713 respondentów. Próba badawcza była wystarczająco zróżnicowana ze względu na podstawowe zmienne społeczno-demograficzne: płeć, wiek/klasa i miejsce zamieszkania, co zostało opisane w zestawieniach tabelarycznych, zamieszczonych w analizie wyników badań. Uzyskane dane są wynikami znormalizowanymi (rozkłady maksymalnie zbliżone do rozkładu normalnego) i wystandaryzowanymi (przeliczone na wspólną skalę - skalę stenową), dzięki czemu możemy dokonać porównań pomiędzy 
poszczególnymi rocznikami/klasami. W tabelach przedstawiono także prosty wskaźnik struktury, jakim jest stosunek wyników wysokich (uczniowie osiągający najwyższy poziom na skali stenowej 7-10 punktów) do wyników niskich (uczniowie osiągający od 1 do 4 punktów na skali).

\section{Postawy twórcze vs. odtwórcze uczniów klas I-III - analiza wyników badań}

Analiza wyników znormalizowanych (tab. 1) ujawnia specyficzne tendencje w przemianach postaw twórczych uczniów i wyraźnie wskazuje ich niekorzystny układ, czyli spadek postaw twórczych w kolejnych klasach w wyniku pomiaru dokonanego w badaniach poprzecznych. Ogólnie stwierdzono przewagę postaw twórczych nad odtwórczymi (W:N=1,27), co stanowi wynik względnie pozytywny. Jednak zaobserwowane wstępnie zmiany nie nastrajają optymistycznie, gdyż dominacja ta zmienia swoje ukierunkowanie wraz z postępem edukacji: bardzo wyraźnie widoczna jest przewaga postaw twórczych nad odtwórczymi w klasie pierwszej (W:N=2,13), już w znacznie mniejszym stopniu zaznacza się to klasach drugich (W:N=1,41), zaś tendencja ta jest odwrotna u uczniów w klasach trzecich (W:N=0,88). Można wnioskować, że naturalne cechy „małego twórcy”, spontanicznie podejmującego aktywność twórczą, w toku nauki szkolnej powoli zanikają. Mogą to z jednej strony warunkować naturalne cechy rozwoju, jednak różnica jest na tyle znacząca i konsekwentna, że pozwala postawić hipotetyczny wniosek o możliwym deficycie szkoły w zakresie oddziaływania na kształtowanie się postaw twórczych: zanikają stopniowo czynniki stymulujące i motywujące rozwój postawy twórczej w szkole. Możliwe, że dziecko przystosowując się do warunków życia szkoły, traci swą spontaniczność, bardziej chcąc spełniać formalne wymagania stawiane przez nauczycieli, co blokuje rozwój postawy twórczej.

Tabela 1. Postawa twórcza dzieci w klasach I-III szkoły podstawowej - tendencje zmian (N=713)

\begin{tabular}{|c|c|c|c|c|c|c|c|c|c|c|c|c|}
\hline \multirow{2}{*}{$\begin{array}{l}\text { Poziom } \\
\text { postawy }\end{array}$} & \multicolumn{3}{|c|}{ Ogólem } & \multicolumn{3}{|c|}{ Klasa I } & \multicolumn{3}{|c|}{ Klasa II } & \multicolumn{3}{|c|}{ Klasa III } \\
\hline & $\mathrm{n}$ & $\%$ & W:N & $\mathrm{n}$ & $\%$ & W:N & $\mathrm{n}$ & $\%$ & W:N & $\mathrm{n}$ & $\%$ & W:N \\
\hline Niski (N) & 161 & 22,58 & \multirow{4}{*}{1,27} & 29 & 15,76 & \multirow{4}{*}{2,13} & 49 & 22,58 & \multirow{4}{*}{1,41} & 83 & 26,60 & \multirow{4}{*}{$\mathbf{0 , 8 8}$} \\
\hline Średni (Ś) & 348 & 48,81 & & 93 & 50,54 & & 99 & 45,62 & & 156 & 50,00 & \\
\hline Wysoki (W) & 204 & 28,61 & & 62 & 33,70 & & 69 & 31,80 & & 73 & 23,40 & \\
\hline Razem & 713 & 100,0 & & 184 & 100,0 & & 217 & 100,0 & & 312 & 100,0 & \\
\hline
\end{tabular}

1. Dywergencja wiąże się z gotowością do poszukiwania własnych i oryginalnych rozwiązań, czyli rozumiana jest jako skłonność do reprezentowania wysokiego poziomu giętkości i oryginalności myślenia, bez odwoływania się do gotowych rozwiązań, zaś algorytm pojmuje się jako skłonność do zastosowania znanych i podanych przez inne osoby rozwiązań. Analizując poziom dywergencji (tab. 2) dostrzegamy także specyficzne tendencje. 
Tabela 2. Poziom dywergencji wśród dzieci w klasach 1-3 - tendencje zmian (N=713)

\begin{tabular}{|c|c|c|c|c|c|c|c|c|c|c|c|c|}
\hline \multirow{2}{*}{$\begin{array}{c}\text { Poziom } \\
\text { dywergencji }\end{array}$} & \multicolumn{3}{|c|}{ Ogólem } & \multicolumn{3}{|c|}{ Klasa I } & \multicolumn{3}{|c|}{ Klasa II } & \multicolumn{3}{|c|}{ Klasa III } \\
\hline & $\mathbf{n}$ & $\%$ & W:N & $\mathbf{n}$ & $\%$ & W:N & $\mathbf{n}$ & $\%$ & W:N & $\mathbf{n}$ & $\%$ & W:N \\
\hline Niski (N) & 178 & 24,96 & \multirow{4}{*}{0,66} & 48 & 25,95 & \multirow{4}{*}{$\mathbf{0 , 5 0}$} & 44 & 20,37 & \multirow{4}{*}{1,05} & 86 & 27,56 & \multirow{4}{*}{0,55} \\
\hline Średni (Ś) & 418 & 58,63 & & 113 & 61,08 & & 126 & 58,33 & & 179 & 57,37 & \\
\hline Wysoki (W) & 117 & 16,41 & & 24 & 12,97 & & 46 & 21,30 & & 47 & 15,07 & \\
\hline Razem & 713 & 100,0 & & 185 & 100,0 & & 216 & 100,0 & & 312 & 100,0 & \\
\hline
\end{tabular}

Wyniki pokazują tendencję do niskiego poziomu dywergencji wśród uczniów klas I-III (mierzonego prostym wskaźnikiem wyników wysokich do niskich - W:N=0,66). Wyznacza to jednak bardzo niski wskaźnik uzyskany w klasach I i III (W:N=0,50; 0,55). Najlepiej wypadają w tym zakresie uczniowie klas II (W:N=1,05), co może (choć nie musi) sugerować, że wstępnie poziom dywergencji rośnie (klasa W:N=1,79), będąc efektem zmian rozwojowych, zaś w następstwie wpływu oddziaływań szkoły w kolejnym roku maleje. Możliwymi czynnikami oddziaływującymi na ten stan jest rodzaj i jakość relacji interpersonalnych nawiązywanych z rówieśnikami i osobami dorosłymi w procesie edukacji, a także sposób ich doświadczania przez dzieci w młodszym wieku szkolnym - subiektywne poczucie bycia lubianym, akceptowanym, mile widzianym w grupie versus poczucie osamotnienia, odsunięcia czy w konsekwencji odrzucenia przez grupę. W pierwszym etapie kształcenia w szkole potrzeby społeczne, dotyczące m.in. wejścia w relacje rówieśnicze, stanowią jedno z ważniejszych zadań rozwojowych (Harwas-Napierała 2008).

Niskie wyniki w zakresie poziomu dywergencji oznaczają, że uczeń nie waloryzuje pozytywnie działań wymagających własnego wysiłku intelektualnego, a woli rozwiązania gotowe (których uczy się w szkole?). Zmierzając w kierunku wyższego poziomu dywergencji, co odpowiada na wymagania współczesnego świata i wiąże się z kompetencjami pozwalającymi sobie z nimi radzić, należy otwierać uczniów na oryginalność i innowacyjność, zaś uzyskany wynik pośrednio wskazuje, że dzieje się odwrotnie. Początkowe, związane z wstępną adaptacją do warunków szkolnych, dozwalanie na tworzenie własnych, wychodzących poza utarte schematy i typowe algorytmy działania, projektowanie rozwiązań niestandardowych dokonujące się w atmosferze akceptacji wszystkich pomysłów, może (choć jak zaznaczyłyśmy, to tylko hipoteza), przekształcać się w formalizowanie wymagań stawianych uczniom, traktowane jako działanie mające sprzyjać adaptacji, strukturalizowaniu i ujednolicaniu działań edukacyjnych. Nauczyciel może kierować się tu źle rozumianym dobrem dziecka, które poddawane jest standaryzacji, mającej zapewnić mu formalny sukces edukacyjny. Uczeń, początkowo spontaniczny i nieobawiający się prezentować nawet najdziwniejszych z punktu widzenia nauczyciela rozwiązań, zaczyna kierować się zasadą „,przypodobania się” nauczycielowi, stając się „,dzieckiem przystosowanym”, a to wyklucza częściowo zachowania, które mogą być przez niego traktowane jako niezgodne z oczekiwaniami nauczyciela. 
2. Motywacja twórcza. Działania twórcze wiążą się ze specyficzną motywacją, często ważniejszą dla ich rozwoju od posiadania wyjściowo określonych potencjałów twórczych (tab. 3). Poziom motywacji twórczej można ogólnie określić jako niski (W:N=0,16), czyli widoczna jest tu odwrotna tendencja niż w dywergencji - najniższe wyniki uzyskują uczniowie z klasy II (W:N=0,11), natomiast wstępnie w klasie I są one znacząco wyższe (W:N=0,26), nieco też wzrastając w klasie III (W:N=0,15).

Tabela 3. Poziom motywacji twórczej wśród dzieci w klasach I-III - tendencje zmian (N=713)

\begin{tabular}{|c|c|c|c|c|c|c|c|c|c|c|c|c|}
\hline \multirow{2}{*}{ Poziom } & \multicolumn{3}{|c|}{ Ogólem } & \multicolumn{3}{|c|}{ Klasa I } & \multicolumn{3}{|c|}{ Klasa II } & \multicolumn{3}{|c|}{ Klasa III } \\
\hline & $\mathbf{n}$ & $\%$ & W:N & $\mathbf{n}$ & $\%$ & W:N & $\mathrm{n}$ & $\%$ & W:N & $\mathbf{n}$ & $\%$ & W:N \\
\hline Niski (N) & 169 & 23,70 & \multirow{4}{*}{0,16} & 35 & 18,92 & \multirow{4}{*}{0,26} & 45 & 20,83 & \multirow{4}{*}{0,11} & 89 & 28,53 & \multirow{4}{*}{0,15} \\
\hline Średni (Ś) & 517 & 72,51 & & 141 & 76,22 & & 166 & 76,85 & & 210 & 67,30 & \\
\hline Wysoki (W) & 27 & 3,79 & & 9 & 4,86 & & 5 & 2,32 & & 13 & 4,17 & \\
\hline Razem & 713 & 100,0 & & 185 & 100,0 & & 216 & 100,0 & & 312 & 100,0 & \\
\hline
\end{tabular}

Dominująca jest generalnie tendencja do średniego poziomu motywacji twórczej, co oznacza, iż uczeń równoważy skłonności przystosowawcze i nonkonformistyczne (chce czasem zaskoczyć otoczenie), co nie jest wynikiem negatywnym. Jednak, jeśli założymy, że celem edukacji ma być kształtowanie wysokiego poziomu motywacji twórczej, szkoła zdaje się tego celu nie realizować. Wysoki poziom motywacji twórczej wyznacza chęć zaskakiwania i zadziwiania otoczenia swoimi pomysłami, po to by być zauważonym przez innych, głównie w tym wieku przez nauczyciela. Niewielki odsetek uczniów, których cechuje wysoki poziom tendencji do niekonwencjonalnych działań może pośrednio świadczyć o tym, że uczeń zauważany przez nauczycieli to ten, który spełnia standardowe oczekiwania (uczeń „grzeczny”, czyli przystosowany, kontrolowany). Dokonane analizy wskazują, że takich uczniów, przy 713 badanych, jest jedynie 27 (3,79\%), co zaskakuje w tym „wieku spontaniczności” i ciekawości poznawczej. Mamy świadomość, że motywacja twórcza powinna być stymulowana na wcześniejszych etapach rozwoju (przedszkole, rodzina), jednak można z pewnym prawdopodobieństwem twierdzić, że jeśli nie „zrobiła tego rodzina, to szkoła powinna wyposażyć dziecko w skrzydła i pomóc mu latać” (por. McWhirter i in. 2001: 55), czego raczej nie robi.

3. Radzenie sobie $\mathbf{z}$ sytuacją trudną. Zmienna ta została opisana w koncepcji postaw twórczych w dwóch aspektach - intrapersonalnym (tendencja do podejmowania zadań trudnych, ambitnych, w celu sprawdzenia się, samodoskonalenia, zdolność do szybkiego podejmowania decyzji o działaniu) i interpersonalnym (umiejętność samodzielnego radzenia sobie z zadaniem trudnym, niezależnie od opinii innych osób, brak lęku przed ośmieszeniem, a jednocześnie wysoki poziom empatii).

Aspekt interpersonalny (tab. 4). Wśród uczniów widać bardzo wyraźną tendencję do wysokiego poziomu interpersonalnego radzenia sobie (wynik ogólny - W:N=9,18). Wynik ten z jednej strony budzi zdziwienie, gdyż dzieci w wieku wczesnoszkolnym zależne są od opinii innych osób, szczególnie dorosłych, stąd potrzebują ich wsparcia w podej- 
mowanych działaniach, szczególnie tych o charakterze twórczym (więc trudnych). Jednak z drugiej strony pośrednio potwierdza to może tezę o spontaniczności, ciekawości poznawczej czy tendencji do samodzielnego eksplorowania świata „małych twórców”, pozbawionego lęku przed oceną i ośmieszeniem, a zarazem powiązanego ze skłonnością empatyczną (Krasoń 2011).

Tabela 4. Interpersonalne radzenie sobie z sytuacją trudną wśród dzieci w klasach I-III - tendencje zmian $(\mathrm{N}=713)$

\begin{tabular}{|c|c|c|c|c|c|c|c|c|c|c|c|c|}
\hline \multirow{2}{*}{ Poziom } & \multicolumn{3}{|c|}{ Ogólem } & \multicolumn{3}{|c|}{ Klasa I } & \multicolumn{3}{|c|}{ Klasa II } & \multicolumn{3}{|c|}{ Klasa III } \\
\hline & $\mathbf{n}$ & $\%$ & W:N & $\mathbf{n}$ & $\%$ & W:N & $\mathrm{n}$ & $\%$ & W:N & $\mathrm{n}$ & $\%$ & W:N \\
\hline Niski (N) & 50 & 7,01 & \multirow{4}{*}{9,18} & 10 & 5,41 & \multirow{4}{*}{14,10} & 17 & 7,87 & \multirow{4}{*}{8,24} & 23 & 7,37 & \multirow{4}{*}{7,74} \\
\hline Średni (Ś) & 204 & 28,61 & & 34 & 18,38 & & 59 & 27,31 & & 111 & 35,58 & \\
\hline Wysoki (W) & 459 & 64,38 & & 141 & 76,21 & & 140 & 64,82 & & 178 & 57,05 & \\
\hline Razem & 713 & 100,0 & & 185 & 100,0 & & 216 & 100,0 & & 312 & 100,0 & \\
\hline
\end{tabular}

Widoczna jest jednak rozwojowo negatywna tendencja w kierunku konsekwentnego spadku samodzielnego radzenia sobie z problemami twórczymi, a więc wzrostu zależności działania od oceny innych osób, warunkowanej lękiem przed ośmieszeniem się, co może wskazywać na negatywne doświadczenia szkolne w tym zakresie, skutkujące zarazem zmniejszaniem się skłonności empatycznej. Można założyć, że obrazuje to znaczenie szkoły w zakresie nawiązywania i utrzymywania relacji z innymi, wskazując, że każdy uczeń może w niej trenować umiejętność funkcjonowania w grupie, w relacjach z innymi, rozwiązując różne trudne zadania. Może też rozwijać umiejętności współpracy w grupie, zdolności do empatycznego rozumienia innych, ograniczania egocentryzmu i tendencji rywalizacyjnych.

Zaobserwowana tendencja do konsekwentnego zwiększania się wagi oceny innych, szczególnie dorosłych (nauczycieli), ale też i rówieśników, w podejmowaniu działań twórczych, wskazuje jednocześnie na swoistą blokadę jaką ta ocena stanowi dla rozwoju postaw twórczych (klasa I - W:N=14,1; klasa II - W:N=8,24; klasa III - W:N=7,74): spadek samodzielności w działaniu jest niewątpliwie negatywnym prognostykiem rozwoju postaw twórczych, sugerować bowiem może problemy z samooceną i poczuciem własnej wartości, które generowane są przez negatywne oceny płynące z zewnątrz, blokując odwagę do podejmowania działań trudnych (więc twórczych). W kontekście deficytów dywergencji i motywacji twórczej, które wykazują tendencję wzrostową, można sądzić, że właśnie negatywne doświadczenia związane z ocenianiem przez innych, szczególnie w szkole, stanowią blokadę rozwoju twórczości dziecka, co więcej ją hamują. Można hipotetycznie założyć, że szkoła uczy powściągania naturalnych dla „małego twórcy” cech, który z lęku przed oceną i ośmieszeniem stara się przystosować do obowiązujących standardów (,nie wychylać się”), zaś negatywne doświadczenia z tym związane mogą zakłócać też rozwój zdolności empatycznych. 
Aspekt intrapersonalny radzenia sobie z sytuacją trudną (tab. 5), obrazuje tendencję do podejmowania zadań trudnych i ambitnych w celu sprawdzenia się i samodoskonalenia, co realizowane jest bez „odwlekania” decyzji o działaniu.

Tabela 5. Intrapersonalne radzenie sobie z sytuacją trudną wśród dzieci w klasach I-III - tendencje zmian $(\mathrm{N}=713)$

\begin{tabular}{|c|c|c|c|c|c|c|c|c|c|c|c|c|}
\hline \multirow{2}{*}{ Poziom } & \multicolumn{3}{|c|}{ Ogólem } & \multicolumn{3}{|c|}{ Klasa I } & \multicolumn{3}{|c|}{ Klasa II } & \multicolumn{3}{|c|}{ Klasa III } \\
\hline & $\mathrm{n}$ & $\%$ & W:N & $\mathrm{n}$ & $\%$ & W:N & $\mathrm{n}$ & $\%$ & W:N & $\mathbf{n}$ & $\%$ & W:N \\
\hline Niski (N) & 421 & 59,05 & \multirow{4}{*}{0,13} & 105 & 56,76 & \multirow{4}{*}{0,20} & 126 & 58,33 & \multirow{4}{*}{0,10} & 190 & 60,90 & \multirow{4}{*}{0,12} \\
\hline Średni (Ś) & 236 & 33,10 & & 59 & 31,89 & & 77 & 35,65 & & 100 & 32,05 & \\
\hline Wysoki (W) & 56 & 7,85 & & 21 & 11,35 & & 13 & 6,02 & & 22 & 7,05 & \\
\hline Razem & 713 & 100,0 & & 185 & 100,0 & & 216 & 100,0 & & 312 & 100,0 & \\
\hline
\end{tabular}

Widoczna jest tu tendencja do dominacji wyników niskich (W:N=0,13), co wskazuje na naturalną dla tego okresu rozwoju tendencję do poszukiwania wsparcia u innych i akceptacji z ich strony w sytuacji twórczej, ze względu na nieustalone jeszcze poczucie własnej wartości, czyli ograniczone poczucie, że można „polegać na sobie samym” w sytuacjach nowych, więc trudnych. Dominacja wyników niskich dowodzi, że uczeń preferuje zadania łatwiejsze, odwlekając też lękowo czas podjęcia rozwiązywania zadań trudnych, co wynikać może z pragnienia, by jego rozwiązania były akceptowane przez otoczenie, bo to potwierdza jego jeszcze nieustalone poczucie własnej wartości. Dążenie do uzyskania akceptacji własnych działań twórczych przez otoczenie dowodzi pośrednio, że w szkołach występuje deficyt działań wspierających oraz umacniających ucznia w pozytywnych przekonaniach na temat siebie, typu: „dam radę”, „mogę sobie poradzić sam”, bo „potrafię” i „nikt nie będzie się ze mnie śmiał”, pozostawiając ucznia w sferze niepewności: „nie wiem, czy podołam”, „nie wiem, czy innym się to spodoba”, „co powiedzą inni”, ,jak mnie ocenią”.

Ze względu na dominację wyników niskich we wszystkich klasach, co rozwojowo jest uzasadnione, incydentalnie niemalże pojawiają się wyniki wysokie, stąd różnice pomiędzy poszczególnymi klasami są niewielkie, choć wskazują na tendencję spadkową w zakresie radzenia sobie intrapersonalnego. Nie napawa optymizmem fakt, że grupa osób, która te zdolności posiada w stopniu wysokim, obejmowała jedynie 56 osób w całej próbie, co przy ogólnej liczebności ( $\mathrm{N}=713)$ stanowi niewielki jej odsetek $(7,85 \%)$, jednak można uznać to za uzasadnione rozwojowo. Natomiast większy pesymizm budzi fakt, iż w toku celowej i zaplanowanej edukacji szkolnej obserwujemy zamiast tendencji rosnącej, raczej - choć słabo zaznaczającą się - tendencję do regresji. Wysokie wartości tej zmiennej bowiem niemal dwukrotnie częściej pojawiają się u pierwszoklasistów ( $\mathrm{W}: \mathrm{N}=0,20)$, niż w dwu następnych klasach (klasa druga - W:N=0,10; klasa trzecia - W:N=0,12). Cel edukacji do twórczości rysuje się dosyć jasno, a wiąże się ze wzmacnianiem umiejętności samodzielnego radzenia sobie, co buduje poczucie własnej wartości, ale w sposób zrównoważony, czyli bez obawy poszukiwania wsparcia społecznego w działaniach twórczych, co z kolei kształtuje umiejętność współpracy z innymi w rozwiązywaniu zadań trudnych, bo nowych (twórczych). 


\section{Refleksja końcowa zamiast dyskusji}

Przeprowadzona w toku ich analizy dyskusja wyników, pozwala wnioskować, że w edukacji dzieci młodszych poszukiwać należy nowatorskich strategii edukacji, których celem jest stymulowanie rozwoju ich potencjału twórczego, tak by procentowało to w kolejnych etapach edukacji. Wiemy, że dzieci w młodszym wieku szkolnym nie posiadają gotowej wiedzy czy umiejętności, ale charakteryzują się spontanicznością, są otwarte na nowe rozwiązania, a potrzeba twórczości jest dla nich naturalna, stąd cechy te należy wykorzystać w planowym kształtowaniu postaw twórczych i innowacyjnych. Jak sugerują uzyskane wyniki, tak się jednak nie dzieje ${ }^{1} \mathrm{w}$ pierwszym, najważniejszym etapie nauki szkolnej, gdyż dynamika rozwoju właściwości świadczących o twórczym zachowaniu jest zbyt mała, a nawet $\mathrm{w}$ większości wskazuje na tendencje regresywne. Z badań Krzysztofa Szmidta (2018: 121), dotyczących analizy różnorodnych programów nauczania twórczości wynika, iż w wychowaniu do twórczości chodzi o całą postawę twórczą (aspekt poznawczy, emocjonalny oraz behawioralny). Twórczość nie jest bowiem tylko fenomenem umysłowym i nie wystarczy pobudzanie jedynie procesów poznawczych (myślenia twórczego). Zaprezentowane w niniejszym artykule badania stanowią w naszym przekonaniu przyczynek do przemyślenia postaw przejawianych przez uczniów w zakresie wszystkich trzech składników postaw twórczych, aby móc działać inaczej niż dotychczas, zmienić charakter i ukierunkowanie swoich działań ze sfery poznawczej na emocjonalną i behawioralną. Podkreślamy także, że nie ma możliwości dokonania odniesień do badań empirycznych nad postawami twórczymi dzieci w młodszym wieku szkolnym, gdyż nie prowadzono ich w takim ujęciu jak nasze - zwykle dotyczą one twórczości realnej, a nie potencjalnej, której wskaźnikiem są przekonania i nastawienia twórcze dziecka (Krasoń 2005, 2012, 2013). Pracując nad twórczymi możliwościami dziecka od najwcześniejszych lat jego życia, przyczyniamy się do ukształtowania postawy twórczej, której rozwój jest warunkowany przez jakość stymulacji, która powinna być dla dziecka dostępna w środowisku społeczno-kulturalnym, w tym także szkolnym.

\section{Literatura}

Bradshaw J. (1994), Zrozumieć rodzinę: rewolucyjna droga odnalezienia samego siebie. Warszawa, IPZiT.

Brzezińska A. (1988), Aktywność własna jako wizerunek kształtowania się postawy twórczej dzieci $w$ wieku przedszkolnym, „Wychowanie w Przedszkolu”, 1.

Dydra B. (2004), Rozwijanie twórczości i inteligencji emocjonalnej dzieci i młodzieży. Kraków, „Impuls".

Harwas-Napierała B. (2008), Charakterystyka okresów życia. W: B. Harwas-Napierała, J. Trempała (red.), Psychologia rozwoju człowieka, t. 2. Warszawa, Wydawnictwo Naukowe PWN.

1 W badaniach realizowanych w okresie późniejszym, gdzie różne wymiary postaw twórczych stanowiły korelat adaptacji do warunków szkoły, jednak na próbie niereprezentatywnej, uzyskano odmienne wyniki (Wysocka 2014: 127-152). 
Karwowski M. (2009a), Klimat szkoły a zdolności twórcze uczniów: w poszukiwaniu prokreatywnej synergii, „Ruch Pedagogiczny”, 5-6.

Karwowski M (2009b), Oblicza uczniowskiej kreatywności, „Psychologia w Szkole”, 4.

Kozielecki J. (1995), Koniec wieku nieodpowiedzialności. Warszawa, Jacek Santorski \& Co.

Krasoń K. (2005), Dziecięce odkrywanie tekstu literackiego - kinestetyczne interpretacje liryki. Katowice, Wydawnictwo UŚ.

Krasoń K. (2011), Skala Postaw Twórczych i Odtwórczych (SPTO). Podręcznik testu - wersja dla uczniów szkoły podstawowej klas I-III. Kraków, Krakowskie Towarzystwo Edukacyjne.

Krasoń K. (2013), Intersemiotic interpretation of music and creative activity of a seven-year-old child (based on the child's motional behavior profile), "The New Educational Review", 2(28).

Krasoń K. (2013), Kilka cierpkich uwag o teatrze w edukacji wczesnoszkolnej, ale i poszukiwanie rozwiązań rzeczywistej aktywności nacechowanej twórczo, „Problemy Wczesnej Edukacji”, 1.

Kubicka D. (1999), Jak rozpoznać, czy ktoś jest osobą twórcza, czyli o mierzeniu twórczości, „Nowa Polszczyzna", 5.

Kubicka D. (2005), Strategie i techniki badania twórczości. W: A. Tokarz (red.): W poszukiwaniu zastosowań psychologii twórczości. Kraków, Wydawnictwo UJ.

Limont W. (2004), Szkoła - szansa czy zagrożenie dla ucznia zdolnego?, „Psychologia w Szkole”, 3.

Limont W. (2005), Teoria i praktyka edukacji uczniów zdolnych. Kraków, Oficyna Wydawnicza „Impuls".

McWhirter J.J., McWhirter B.T., McWhirter A.M., McWhirter E.H. (2001), Zagrożona młodzież. Warszawa, PARPA,

Nęcka E. (2001), Psychologia twórczości. Gdańsk, GWP.

Robinson K., Aronica L. (2015), Kreatywne szkoły. Oddolna rewolucja, która zmienia edukację. Kraków, Wydawnictwo ELEMENT.

Szmidt K.J. (2018), Kreatywność - twórczość - postawa twórcza. Próba systematyzacji pojęć i teorii. W: B. Śliwerski, A. Rozmus (red.): Alternatywy w edukacji. Kraków, Oficyna Wydawnicza Impuls.

Tokarz A. (2005), Dynamika procesu twórczego. Kraków, Wydawnictwo UJ.

Wysocka E. (2014), Postawy twórcze versus odtwórcze dzieci w młodszym wieku szkolnym i „ewolucja” tych postaw jako egzemplifikacja idei transgresji w edukacji szkolnej, „Chowanna”, t. 2(43). 